\title{
Complexation of Alkali Metal Cations by a Tertiary Amide Calix[4]Arene Derivative in Strongly Cation Solvating Solvents
}

Katarina Leko, ${ }^{1}$ Nikola Bregović, ${ }^{1}$ Marija Cvetnić, ${ }^{1}$ Nikola Cindro, ${ }^{1}$ Marina Tranfić Bakić, ${ }^{2}$ Josip Požar,,${ }^{1, *}$ Vladislav Tomišićc,*

\footnotetext{
1 Division of Physical Chemistry, Department of Chemistry, Faculty of Science, University of Zagreb, Horvatovac 102a, HR-10000 Zagreb, Croatia

2 Department of Chemistry and Biochemistry, Faculty of Food Technology and Biotechnology, University of Zagreb, Pierottijeva 6, HR-10000 Zagreb, Croatia

*Corresponding authors' e-mail addresses: pozar@chem.pmf.hr, vtomisic@chem.pmf.hr
}

RECEIVED: July 20, 2017 * REVISED: August 8,2017 * ACCEPTED: August 17, 2017

THIS PAPER IS DEDICATED TO PROF. MIRJANA METIKOŠ-HUKOVIĆ ON THE OCCASION OF HER BIRTHDAY

\begin{abstract}
The complexation of alkali-metal cations with calix[4]arene tertiary amide derivative (L) was studied in N-methylformamide (NMF), $\mathrm{N}, \mathrm{N}$-dimethylformamide (DMF), and dimethyl sulfoxide (DMSO) by means of microcalorimetric and UV spectrophotometric titrations. The Gibbs energies, enthalpies, and entropies for transfer of reactants and products from $\mathrm{N}$-methylformamide to other solvents were determined. Favorable enthalpic contribution to overall stability was found to be the most important for all complexation reactions, especially in the case of $\mathrm{NaL}^{+}$ formation, resulting in an affinity peak of $\mathrm{L}$ for this cation. The complexation entropy changes were always unfavorable. The ligand dissolution was endothermic in all solvents, accompanied by positive solution entropy. The highest complex stability constants were determined in NMF, whereas in DMSO the affinity of $\mathrm{L}$ towards alkali metal cations was the lowest. An interesting interplay between the transfer enthalpies and entropies of the reactants and complexes was revealed and discussed in detail.
\end{abstract}

Keywords: tertiary amide calix[4]arene derivative, microcalorimetry, solvation effect, alkali metal cation complexation.

\section{INTRODUCTION}

D URING the past several decades a vast variety of calixarene derivatives has been synthesized and their complexation reactions with most diverse species has been studied. ${ }^{[1]}$ These macrocyclic ligands can be relatively easily functionalized at both upper and lower calixarene rim, which allows preparation of efficient receptors for charged and neutral species. ${ }^{[2-4]}$ As a result, this class of compounds has been exploited for different tasks, such as catalysis, ion extraction, ${ }^{[5]}$ purification, ${ }^{[6]}$ electrochemical and fluorimetric sensing, ${ }^{[7,8]}$ etc. In recent advancements the potentials of calixarene based compounds as biomimetics, drugdelivery systems, ${ }^{[9]}$ ion chanells, ${ }^{[10,11]}$ nanomaterial components ${ }^{[12,13]}$ etc. have been explored. Although calixarene chemistry can be regarded as a well-developed field, several issues, e.g. increasing their solubilities in polar solvents (especially water), ${ }^{[14]}$ enhancing selectivities towards the particular species and improving the synthetic procedures for their preparation, still need to be addressed in order to facilitate evolution of the calixarene-based compounds.

In the context of alkali metal cation complexation, the calixarene derivatives containing electron-rich atoms (i.e. ester, ketone, and amide derivatives) have been affirmed as highly effective receptors due to a well-defined binding site with numerous donor atoms directed towards the guest. $[4,5,8,15,16,17]$ Among these derivatives, the compounds comprising tertiary-amide groups proved to be the most efficient, exhibiting remarkably high affinities towards alkali metal cations. ${ }^{[4,5,17,18]}$ The selectivity of the calixarenebased receptors is in great part a result of size complementarity of host cavity and the cation. Therefore, calix[4]arenes usually bind sodium cation most effectively, whereas calix[6]arene analogues bind better larger cations, like $\mathrm{Rb}^{+}$and $\mathrm{Cs}^{+} .[4,17]$

An important aspect which governs the stability of the complexes is certainly the solvent effect. Namely, a significant change in solvation of both receptor and the cation 


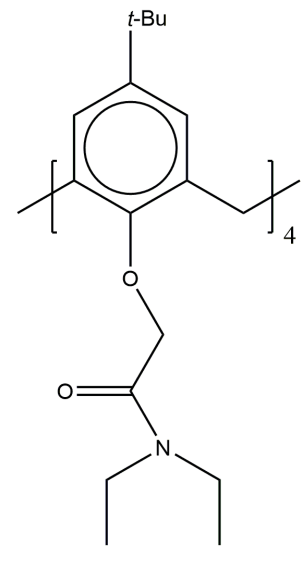

Figure 1. Structure of compound L.

is expected upon complexation, since the solvent molecules surrounding the cation are mostly replaced by the donor atoms of the ligand.[16,17] Thus, one of the prerequisites of further rational receptor design with the aim of improving their properties and obtaining high affinity, coupled with peak selectivity, is understanding the thermodynamics of the binding process, including the solvation influence, in as much detail as possible. This agenda requires extending the corresponding reasearch to most diverse media (solvents) in order to define specific requirements, and determine drawbacks and advantages in different systems. Significant advancement towards this goal has been made by several groups. However, most of the reported studies of alkali metal calixarene complexes were focused on a rather limited series of solvents. The most often used solvents are methanol and acetonitrile, $[4,5,15,19,20]$ whereas the strongly cation-solvating media (e.g. $\mathrm{N}, \mathrm{N}$-dimethylformamide and dimethyl sulfoxide) were rarely investigated. [21-23] Therefore, we made an effort to study the alkali metal complexation by calixarenes in such media, paying special attention to solvent effects on the thermodynamics of the studied reactions.

In the present work we have investigated the alkali metal cation complexation with tertiary amide calixarene derivative, namely, 5,11,17,23-p-tert-butyl-25,26,27,28tetra-diethylacetamide-calix[4]arene (L, Figure 1) in $\mathrm{N}$ methylformamide (NMF), N,N-dimethylformamide (DMF), and dimethyl sulfoxide (DMSO). The solvent selection was made taking into account the differences in their cation, complex, and ligand solvation abilities and the possibility of ligand-solvent hydrogen bonding, with the aim of gaining a more detailed insight in the solvent effects gained from the gathered thermodynamic data. As already mentioned, these solvents can be regarded as strongly cation-solvating ones, which is expected to significantly hinder the complexation reactions, allowing only the study of ligands with high intrinsic affinity towards cations. It was previously shown that $\mathbf{L}$ binds alkali metal cations in both acetonitrile and methanol quite strongly. ${ }^{[17,18]}$ Hence, this ligand was chosen as a perspective candidate which could form sufficiently stable complexes (allowing reliable stability constant determination) even in the highly competitive media.

\section{EXPERIMENTAL}

\section{Materials}

Compound $\mathbf{L}$ was prepared according to the procedure described elsewhere. ${ }^{[24]}$ The solvents, $\mathrm{N}$-methylformamide (Sigma-Aldrich, $99 \%$ ), N,N-dimethylformamide (SigmaAldrich, HPLC Grade) and dimethyl sulfoxide (Sigma-Aldrich, HPLC Grade) were used without further purification. The salts used for the investigation of compound $\mathbf{L}$ complexation were $\mathrm{LiClO}_{4}$ (Sigma Aldrich $99.99 \%$ ), $\mathrm{NaClO}_{4}$ (Sigma Aldrich $98+\%$ ), $\mathrm{KClO}_{4}$ (Merck, p.a.), and $\mathrm{RbNO}_{3}$ (Sigma, $99.7 \%$ ).

\section{Calorimetry}

Microcalorimetric measurements were performed by an isothermal titration calorimeter Microcal VP-ITC at $25.0^{\circ} \mathrm{C}$. In the calorimetric titrations, the enthalpy changes obtained upon stepwise, automatic addition of alkali metal salt solution to solution of $\mathbf{L}$ were recorded. The concentration of titrant (from $c=2 \times 10^{-3} \mathrm{~mol} \mathrm{dm}^{-3}$ up to $1 \times 10^{-1} \mathrm{~mol}$ $\mathrm{dm}^{-3}$ ) was chosen depending on the stability of the complex formed. The receptor concentration was in all titrations $2 \times$ $10^{-4} \mathrm{~mol} \mathrm{dm}^{-3}$. Blank experiments were carried out in order to make corrections for the enthalpy changes corresponding to titrant dilution in pure solvent. The dependence of successive enthalpy change on the titrant volume was processed by non-linear least-squares fitting procedure using OriginPro 7.5 program. ${ }^{[25]}$ Titrations for each cation/ligand system were done in triplicate.

The calorimeter reliability was checked by carrying out the complexation of barium(II) by 18 - crown- 6 in water at $25.0^{\circ} \mathrm{C}$. The results obtained $\left(\log K=3.74, \Delta_{\mathrm{r}} H=-30.9 \mathrm{~kJ}\right.$ $\left.\mathrm{mol}^{-1}\right)$ were in good agreement with the literature values $\left(\log K=3.73, \Delta_{\mathrm{r}} H=-31.5 \mathrm{~kJ} \mathrm{~mol}^{-1}\right) .{ }^{[26]}$

\section{Spectrophotometry}

Spectrophotometric titrations were carried out at (25.0 \pm $0.1)^{\circ} \mathrm{C}$ by means of a Varian Cary 60 spectrophotometer equipped with a thermostatting device. The spectral changes of $L$ solution $\left(V_{0}=2.2 \mathrm{~cm}^{3}, c_{0}=2 \times 10^{-4} \mathrm{~mol} \mathrm{dm}^{-3}\right)$ were recorded upon stepwise addition of $\mathrm{RbNO}_{3}\left(c=4 \times 10^{-}\right.$ ${ }^{2} \mathrm{~mol} \mathrm{dm}^{-3}$ ) solution directly into the measuring quartz cell (Hellma, Suprasil QX, $I=1 \mathrm{~cm}$ ). Absorbances were sampled at $1 \mathrm{~nm}$ intervals, with an integration time of $0.2 \mathrm{~s}$. The measurements were done in triplicate. The spectra were corrected for dilution and absorbance of nitrate. The obtained spectrophotometric data were processed using HYPERQUAD program. ${ }^{[27]}$ 


\section{Solubility Measurements}

Saturated solutions of $\mathbf{L}$ were prepared by adding excess amounts of the solid to the solvents explored. The obtained mixtures were left in a thermostat at each temperature $(20$, $25,30,35,40^{\circ} \mathrm{C}$ ) for several days in order to equilibrate. After the equilibrium was reached, aliquots of solutions were taken for the solubility determination. The concentrations of saturated solutions of $\mathbf{L}$ were determined spectrophotometrically by means of an Agilent Cary 60 spectrophotometer equipped with a thermostatting device. The molar absorption coefficients of $\mathbf{L}$ were obtained from Lambert-Beer law by recording UV spectra of a series of $\mathbf{L}$ solutions of known concentrations. The solution enthalpies of the compounds were determined from the temperature dependence of solubilities by means of van't Hoff equation. Solvate formation was tested by placing a known amount of $\mathbf{L}(m=20 \mathrm{mg})$ in a desiccator where it was exposed to a saturated atmosphere of the investigated solvents for several days and weighed afterwards. No increase of mass was observed which indicated that no solvate formation occurred.

\section{RESULTS AND DISCUSSION}

\section{Solvation of $\mathbf{L}$}

The solubilities of $\mathbf{L}$ in the investigated solvents are reported in Tables 1 and S1 (Supporting Information). The standard solution Gibbs energies of the receptor (Table 1) were calculated from the solubility data by means of the equation:

$$
\Delta_{\mathrm{sol}} G^{\circ}=-R T \ln K_{\mathrm{s}}^{\circ}=-R T \ln \left(\gamma_{\mathrm{L}} \mathrm{s} / \mathrm{c}^{\circ}\right) \approx-R T \ln \left(s / \mathrm{c}^{\circ}\right)
$$

where $s$ denotes solubility, $c^{\circ}$ is the standard concentration $\left(1 \mathrm{~mol} \mathrm{dm}^{-3}\right)$, and $\gamma_{\mathrm{L}}$ stands for the activity coefficient of the compound (assumed to be close to unity). Solution enthalpies and entropies (Table 1) were determined using van't Hoff equation and the corresponding plots are shown in Figures 2 and S1 (Supporting Information).

The standard thermodynamic solution parameters are rather similar in all cases. As expected, the strongly unfavorable $\Delta_{\text {sol }} H^{\circ}$ values are partly compensated by positive entropy changes which are mainly a result of ligand $L$ lattice disruption. The solvation of $\mathbf{L}$ in DMF is thermodynamically most advantageous as a consequence of the least endothermic dissolution. The lowest solubility in DMSO is a result of enthalpically more demanding ligand dissolution, while the $\Delta_{\text {sol }} S^{\circ}$ is rather similar to that in DMF. The dissolution in NMF is entropically most favorable, but also most endothermic. Such an interplay between the solution thermodynamic parameters eventually leads to the fact that solubility of $\mathbf{L}$ in NMF is between those observed in DMF and DMSO.
Table 1. Solubilities of $\mathrm{L}$ at $25{ }^{\circ} \mathrm{C}$ and standard thermodynamic parameters of ligand solution in investigated solvents determined by means of van't Hoff equaiton.

\begin{tabular}{cccccc}
\hline solvent & $10^{3} \mathrm{~s}(\mathrm{~L}) / \mathrm{c}^{\circ}$ & $\frac{\Delta_{\mathrm{sol}} \mathrm{G}^{\circ}}{\mathrm{kJ} \mathrm{mol}^{-1}}$ & $\frac{\Delta_{\mathrm{sol}} \mathrm{H}^{\circ}}{\mathrm{kJ} \mathrm{mol}^{-1}}$ & $\frac{\Delta_{\mathrm{sol}} \mathrm{S}^{\circ}}{\mathrm{J} \mathrm{K}^{-1} \mathrm{~mol}^{-1}}$ \\
\hline DMF & 33.7 & 8.4 & 25.7 & 57.7 \\
NMF & 10.4 & 11.3 & 33.5 & 74.7 \\
DMSO & 2.26 & 15.1 & 31.8 & 55.5 \\
\hline
\end{tabular}

\section{Cation Complexation}

The complexation of $\mathrm{Li}^{+}, \mathrm{Na}^{+}, \mathrm{K}^{+}$, and $\mathrm{Rb}^{+}$cations with $\mathrm{L}$ was studied by means of ITC and the recorded thermograms for titrations with $\mathrm{Na}^{+}$are shown in Figures 3a-5a, (the other results are given in Supporting Information, Figures S2aS7a). In all cases the stepwise addition of alkali metal salts resulted in negative enthalpy changes. The standard reaction enthalpies and equilibrium constants (hence the standard reaction Gibbs energies) for the complexation reactions were calculated by a least-squares non-linear regression analysis of calorimetric titration data (Table 2). Formation of 1:1 complexes was assumed which resulted in good agreement of the experimental and calculated data (Figures 3b-5b, S2b-S7b, Supporting Information). Standard complexation entropies were calculated from the complexation enthalpies and Gibbs energies. The obtained standard thermodynamic complexation parameters are listed in Table 2.

The reliability of calorimetrically determined thermodynamic parameters (in particular reaction enthalpy and entropy) for $\mathrm{Rb}^{+}$complexation in NMF is somewhat lower than in the case of other alkali metal cations because of the relatively high dilution enthalpy of rubidium nitrate

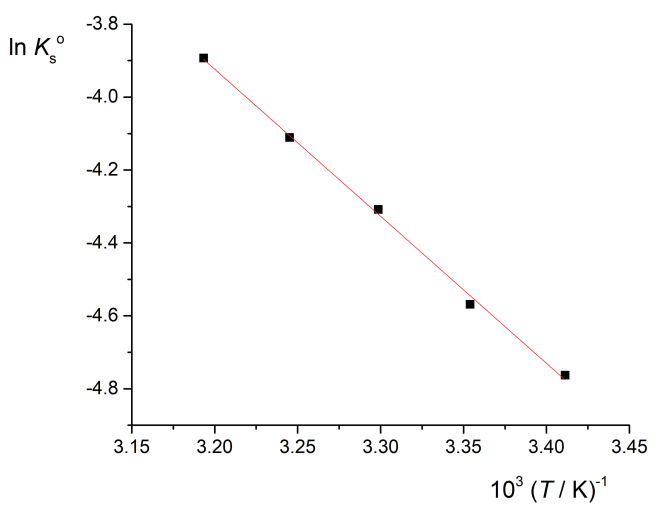

Figure 2. Temperature dependence of standard solubility constant for $\mathrm{L}$ in $\mathrm{N}$-methyl formamide. a experimental; calculated by means of van't Hoff equation. 
(a)

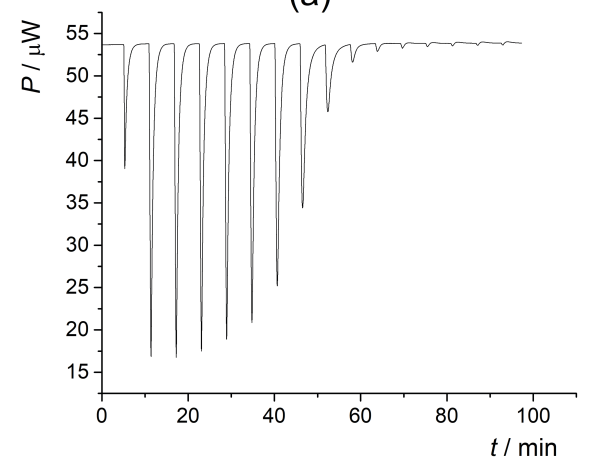

(b)

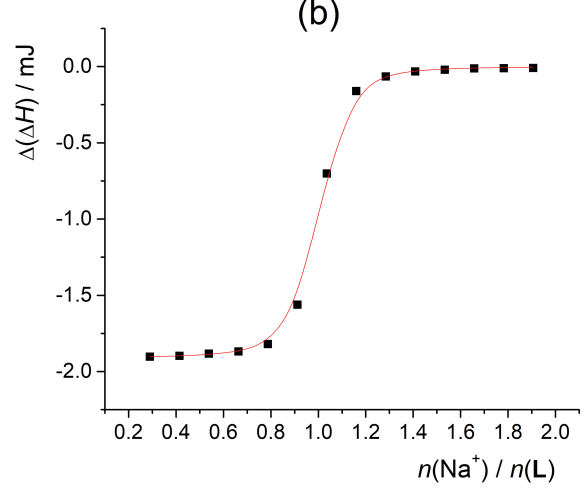

Figure 3. a) Microcalorimetric titration of $\mathrm{L}\left(c=2 \times 10^{-4} \mathrm{~mol} \mathrm{dm}^{-3}, V=1.42 \mathrm{ml}\right)$ with $\mathrm{NaClO}_{4}\left(c=2 \times 10^{-3} \mathrm{~mol}_{\mathrm{dm}}^{-3}\right)$ in $\mathrm{N}$ methylformamide at $25^{\circ} \mathrm{C}$; b) Dependence of successive enthalpy change on $n\left(\mathrm{NaClO}_{4}\right) / n(\mathrm{~L})$ ratio. a experimental; calculated
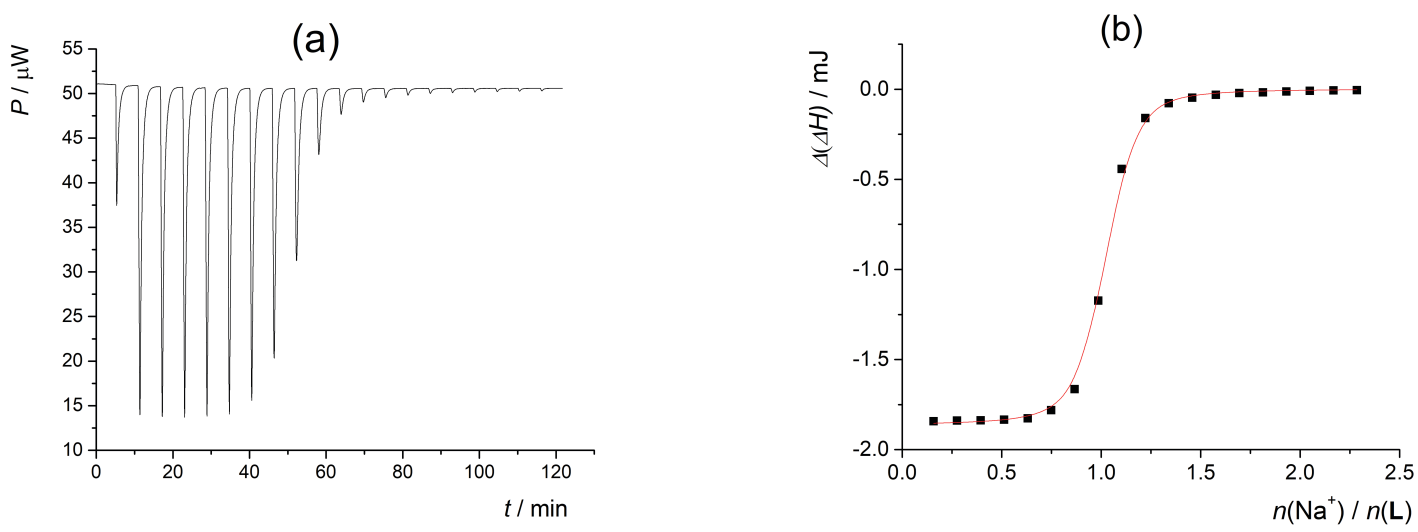

Figure 4. a) Microcalorimetric titration of $\mathrm{L}\left(c=2 \times 10^{-4} \mathrm{~mol} \mathrm{dm}-3, V=1.42 \mathrm{ml}\right)$ with $\mathrm{NaClO}_{4}\left(c=2 \times 10^{-3} \mathrm{~mol} \mathrm{dm}^{-3}\right)$ in $\mathrm{N}, \mathrm{N}$ dimethylformamide at $25^{\circ} \mathrm{C}$; b) Dependence of successive enthalpy change on $n\left(\mathrm{NaClO}_{4}\right) / n(\mathrm{~L})$ ratio. a experimental; calculated.
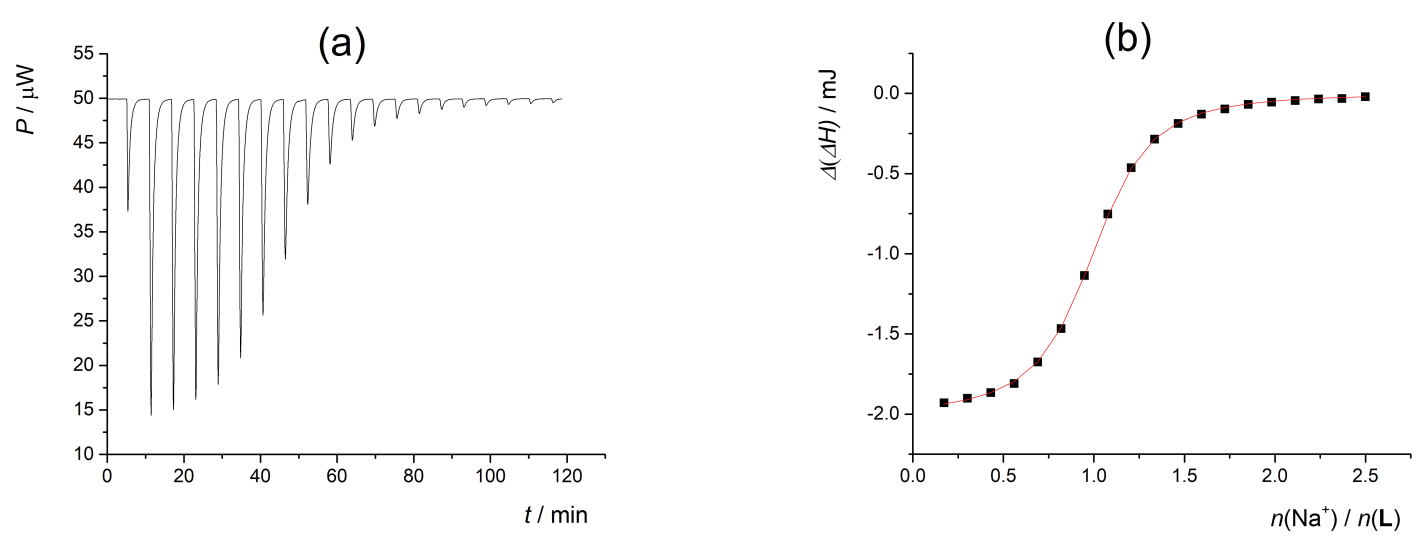

Figure 5. a) Microcalorimetric titration of $\mathrm{L}\left(c=2 \times 10^{-4} \mathrm{~mol} \mathrm{dm}-3, V=1.42 \mathrm{ml}\right)$ with $\mathrm{NaClO}_{4}\left(c=2 \times 10^{-3} \mathrm{~mol} \mathrm{dm}^{-3}\right)$ in dimethylsulfoxide at $25{ }^{\circ} \mathrm{C}$; b) Dependence of successive enthalpy change on $n\left(\mathrm{NaClO}_{4}\right) / n(\mathrm{~L})$ ratio. - experimental; calculated. 
in this solvent. In order to check the accuracy of calorimetrically determined stability constant of $\mathrm{RbL}^{+}$, the rubidium cation complexation in $\mathrm{N}$-methylformamide was also studied spectrophotometrically. Namely, this constant could be readily obtained by the latter method, since significant changes in the UV spectrum of $\mathbf{L}$ occurred upon addition of $\mathrm{RbNO}_{3}$ (Figure 6). As can be seen from the data listed in Table 2, the $\mathrm{RbL}^{+}$stability constant values determined by the two methods (Table 2 ) are in very good agreement.

In DMF and DMSO no evidence of $\mathrm{RbL}^{+}$complex formation was found. Furthermore, no complexation of $\mathrm{Li}^{+}$in DMSO was detected, neither calorimetrically nor spectrophotometrically, while binding of $\mathrm{Cs}^{+}$by $\mathbf{L}$ could not be observed in any of the investigated solvents under the experimental conditions used.

In all studied solvents the $\mathrm{NaL}^{+}$complex was significantly more stable than those with other investigated alkali metal cations. As in the case of the previously studied complexation in acetonitrile and methanol, ${ }^{[17]}$ that is primarily a consequence of most favourable reaction enthalpy. This can be explained by assuming that the interactions of receptor with $\mathrm{Na}^{+}$cation are the strongest, due to its size complementarity with the binding site of L. As already stated, similar behaviour has been detected for many other lower-rim calix[4] arene derivatives. ${ }^{[4,5,8,15-17]} \quad$ All herein studied complexation processes were accompanied by negative entropy change, which can be, at least partly, explained by the loss in translational entropy of the reactants upon complexation. The much lower affinity of compound L for lithium cation compared to $\mathrm{Na}^{+}$in NMF is primarily a result of far less pronounced enthalpic contribution to complexation Gibbs energy. This is a consequence of two factors: a) weaker interactions between smaller $\mathrm{Li}^{+}$and oxygen donor atoms of the receptor $\mathbf{L}$, and $b$ ) more exothermic solvation of the lithium cation. ${ }^{[28]}$ The ability of lithium to strongly bind the solvent molecules is also reflected in less entropically unfavourable complexation in comparison with sodium. Namely, the release of larger number of NMF molecules upon lithium complexation counterbalances the negative entropy changes arising from the decrease in the translational entropy of the reactants.

Further on, it was found that $\mathbf{L}$ formed rather stable complexes with $\mathrm{K}^{+}$in NMF in spite of relatively unfavourable complexation entropy. This is again a result of negative complex formation enthalpy, which is larger (more negative) compared to analogous value for $\mathrm{LiL}^{+}$, but still notably less favourable than in the case of $\mathrm{Na}^{+}$complexation in the same solvent. On the other hand, the investigated receptor exhibited far lower affinity for $\mathrm{Rb}^{+}$, which is most likely due to insufficient size compatibility of the cation and the receptor binding site.

The stabilities of $\mathrm{NaL}^{+}$and $\mathrm{KL}^{+}$species in DMSO were approximately one order of magnitude lower than in $\mathrm{N}$ methylformamide and $\mathrm{N}, \mathrm{N}$-dimethylformamide, which is mostly a consequence of less favorable standard complexation enthalpies in this solvent, whereas the reaction entropy of $\mathrm{Na}^{+}$complexation remained practically unchanged in all three solvents. It should be noted that the $\mathrm{NaL}^{+}$stability constant is greater than $10^{5}$ which is a remarkably high value given the competitive reaction medium.

A more detailed interpretation of the solvent influence on the cation complexation thermodynamics can be obtained by taking into account the standard thermodynamic parameters of reactants and complex transfer $\left(\Delta_{\mathrm{t}} X^{\circ}\right.$; $X=G, H, S$ ) between the solvents. In this discussion NMF is used as a referent solvent and parameters for transfers from NMF to other solvents were calculated and compared. The $\Delta_{\mathrm{t}} G^{\circ}, \Delta_{\mathrm{t}} H^{\circ}, \Delta_{\mathrm{t}} \mathrm{S}^{\circ}$ for ligand transfers were obtained from the differences in the corresponding thermodynamic parameters for solution in the two solvents, whereas
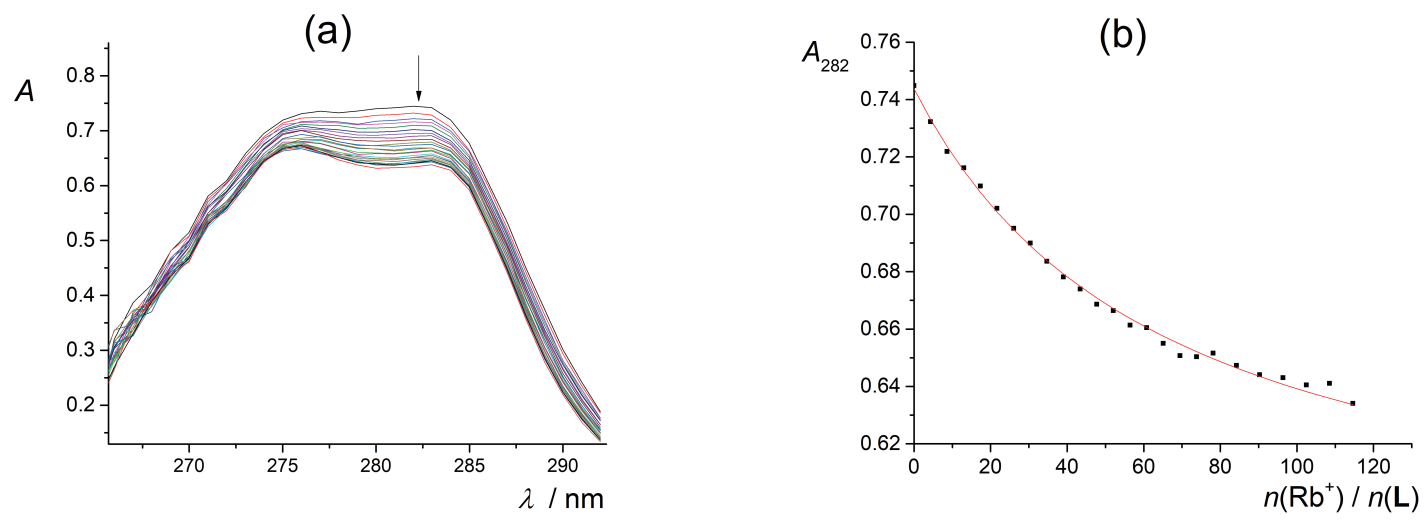

Figure 6. a) Spectrophotometric titration of $\mathrm{L}\left(c=2 \times 10^{-4} \mathrm{~mol} \mathrm{dm}-3, V_{0}=2.2 \mathrm{~mL}\right)$ with $\mathrm{RbNO}_{3}\left(c=4 \times 10^{-2} \mathrm{~mol} \mathrm{dm}^{-3}\right)$ in $\mathrm{N}$-methylformamide. $I=1 \mathrm{~cm} ; \theta=(25.0 \pm 0.1)^{\circ} \mathrm{C}$. The spectra are corrected for dilution and absorbance of nitrate. b) Dependence of absorbance at $282 \mathrm{~nm}$ on $n\left(\mathrm{RbNO}_{3}\right) / n(\mathrm{~L})$ ratio. a experimental; - calculated. 
Table 2. Thermodynamic parameters for complexation of alkali metal cations with compound $\mathrm{L}$ in examined solvents at $25^{\circ} \mathrm{C}$ determined calorimetrically.

\begin{tabular}{|c|c|c|c|c|c|}
\hline solvent & cation & $\log K\left(\mathrm{ML}^{+}\right) \pm \mathrm{SE}$ & $\frac{\Delta_{\mathrm{r}} G^{\circ} \pm \mathrm{SE}}{\mathrm{kJ} \mathrm{mol}^{-1}}$ & $\frac{\Delta_{\mathrm{r}} H^{\circ} \pm \mathrm{SE}}{\mathrm{kJ} \mathrm{mol}^{-1}}$ & $\frac{\Delta_{\mathrm{r}} \mathrm{S}^{\circ} \pm \mathrm{SE}}{\mathrm{JK}^{-1} \mathrm{~mol}^{-1}}$ \\
\hline \multirow[t]{5}{*}{ NMF } & $\mathrm{Li}^{+}$ & $3.254 \pm 0.002$ & $-18.6 \pm 0.1$ & $-27.9 \pm 0.3$ & $-31 \pm 1$ \\
\hline & $\mathrm{Na}^{+}$ & $6.35 \pm 0.01$ & $-36.23 \pm 0.06$ & $-62.89 \pm 0.07$ & $-89.3 \pm 0.4$ \\
\hline & $\mathrm{K}^{+}$ & $3.947 \pm 0.005$ & $-22.53 \pm 0.03$ & $-43.0 \pm 0.2$ & $-67 \pm 2$ \\
\hline & \multirow{2}{*}{$\mathrm{Rb}^{+}$} & $1.70 \pm 0.03$ & $-9.7 \pm 0.2$ & $-40 \pm 3$ & $-99 \pm 10$ \\
\hline & & $1.72 \pm 0.03^{(a)}$ & $-9.8 \pm 0.2^{(\mathrm{a})}$ & & \\
\hline \multirow[t]{3}{*}{ DMF } & $\mathrm{Li}^{+}$ & $3.235 \pm 0.002$ & $-18.46 \pm 0.01$ & $-29.72 \pm 0.08$ & $-37.7 \pm 0.3$ \\
\hline & $\mathrm{Na}^{+}$ & $6.138 \pm 0.003$ & $-35.03 \pm 0.02$ & $-61.25 \pm 0.01$ & $-87.7 \pm 0.3$ \\
\hline & $\mathrm{K}^{+}$ & $3.493 \pm 0.004$ & $-19.94 \pm 0.02$ & $-34.5 \pm 0.1$ & $-48.5 \pm 0.4$ \\
\hline \multirow[t]{2}{*}{ DMSO } & $\mathrm{Na}^{+}$ & $5.223 \pm 0.001$ & $-29.87 \pm 0.01$ & $-56.24 \pm 0.02$ & $-89.67 \pm 0.09$ \\
\hline & $\mathrm{K}^{+}$ & $2.775 \pm 0.002$ & $-15.84 \pm 0.01$ & $-34.8 \pm 0.2$ & $-63.7 \pm 0.2$ \\
\hline
\end{tabular}

(a) Determined spectrophotometrically. SE = standard error of the mean $(N=3)$.

literature data was used for calculations of the analogous parameters for cations (Equation 2). [28,29]

$$
\begin{aligned}
& \Delta_{\mathrm{t}} \mathrm{X}^{\circ}\left(\mathrm{M}^{+}, \mathrm{NMF} \rightarrow \mathrm{S}\right)=\Delta_{\mathrm{t}} \mathrm{X}^{\circ}\left(\mathrm{M}^{+}, \mathrm{H}_{2} \mathrm{O} \rightarrow \mathrm{S}\right)- \\
& \Delta_{\mathrm{t}} \mathrm{X}^{\circ}\left(\mathrm{M}^{+}, \mathrm{H}_{2} \mathrm{O} \rightarrow \mathrm{NMF}\right),
\end{aligned}
$$

where $\mathrm{M}^{+}$stands for alkali metal cation, and $\mathrm{S}$ stands for either DMF or DMSO.

Further on, transfer thermodynamic parameters for $\mathrm{ML}^{+}$complexes were calculated using the following expression:

$$
\begin{aligned}
& \Delta_{\mathrm{t}} X^{\circ}\left(\mathrm{ML}^{+}, \mathrm{NMF} \rightarrow \mathrm{S}\right)=\Delta_{\mathrm{r}} X^{\circ}(\mathrm{S})-\Delta_{\mathrm{r}} X^{\circ}(\mathrm{NMF})+ \\
& \Delta_{\mathrm{t}} X^{\circ}\left(\mathrm{M}^{+}, \mathrm{NMF} \rightarrow \mathrm{S}\right)+\Delta_{\mathrm{t}} X^{\circ}(\mathrm{L}, \mathrm{NMF} \rightarrow \mathrm{S})
\end{aligned}
$$

The thermodynamic functions of all relevant transfer processes are given in Tables 3 and 4.

By inspecting these data, one can observe that the effects of exergonic transfers of the free cations and their complexes with $\mathbf{L}$ from NMF to DMF cancel each other out in cases of $\mathrm{Na}^{+}$and $\mathrm{K}^{+}$. On the other hand, slightly stronger solvation of the receptor in $N, N$-dimethylformamide leads to somewhat higher affinity of the investigated calix[4]arene derivative for $\mathrm{Na}^{+}$and $\mathrm{K}^{+}$in $\mathrm{N}$-methylformamide. In the case of lithium, more exergonic transfer of the free cation in comparison to that of $\mathrm{LiL}^{+}$cancels out the more favorable solvation of free ligand in NMF, which results in practically the same stability constants of $\mathrm{LiL}^{+}$in these two solvents. It should also be noted that $\mathrm{Li}^{+}$and $\mathrm{LiL}^{+}$are the only cations whose solvation is notably more favorable in NMF in comparison to DMF. In the case of free cation this can be explained by considering its high charge density leading to significant reorganization of the structured solvent like NMF (secondary solvation sphere and beyond), which results in favourable $\mathrm{Li}^{+}$solvation in this solvent. The dissection of the corresponding $\Delta_{\mathrm{t}} G^{\circ}$ into the enthalpic and entropic contributions corroborates this explanation. Namely, $\mathrm{Li}^{+}$transfer from NMF to DMF is quite endothermic, whereas the corresponding entropy is negative. The positive $\Delta_{\mathrm{t}} G^{\circ}$ for $\mathrm{LiL}^{+}$transfer from NMF to DMF (while for all other investigated complexes the transfers are exergonic) indicates that only partial desolvation of this cation in NMF occurs upon complexation, i.e. a coordination of $\mathrm{Li}^{+}$by one or several solvent molecules is retained, as this would favor the complex solvation in NMF with respect to DMF. It should be noted that the endothermic transfers of $\mathrm{K}^{+}, \mathrm{Rb}^{+}$, and $\mathrm{KL}^{+}$are compensated with positive transfer entropies, whereas the transfers of $\mathrm{Na}^{+}$as well as its complex with $\mathbf{L}$ from NMF to DMF are both enthalpically and entropically favorable.

As in the case of DMF, the differences in complexation abilities of $L$ in DMSO and NMF can be discussed on the basis of transfer thermodynamic data (Table 4). Again, the transfer of free sodium and potassium ions from NMF is exergonic, but, in contrast to DMF, the $\Delta_{t} G^{\circ}$ values for transfer of the ligand and its complexes are positive. This leads to conclusion that the significant decrease in the cation complex stability in DMSO in comparison to both NMF and DMF is influenced by solvation of all three species involved in the reaction. Furthermore, the transfer of $\mathrm{Li}^{+}$from NMF to DMSO is endergonic, which should introduce a positive impact on the stability of the corresponding complex in the latter solvent. The fact that the complexation of this cation has not been observed in DMSO indicates that the solvation of the complex in this solvent is remarkably less strong. The transfers from NMF to DMSO for all charged species are endothermic, whereby the highest transfer enthalpy was obtained for $\mathrm{KL}^{+}$complex. On the other hand, entropic 
Table 3. Standard thermodynamic parameters of reactants and complexes transfers from NMF to DMF.(a)

\begin{tabular}{ccccc}
\hline \multirow{2}{*}{ Species } & $\frac{\Delta_{\mathrm{t}} \mathrm{G}^{\circ}}{\left.\mathrm{kJ} \mathrm{mol}\right|^{-1}}$ & $\frac{\Delta_{\mathrm{t}} \mathrm{H}^{\circ}}{\mathrm{kJ} \mathrm{mol}^{-1}}$ & $\frac{\Delta_{\mathrm{t}} \mathrm{S}^{\circ}}{\mathrm{J} \mathrm{K}^{-1} \mathrm{~mol}^{-1}}$ \\
\hline $\mathrm{Li}^{+}$ & 10 & 5.6 & -14.8 \\
$\mathrm{Na}^{+}$ & -3 & -1.9 & 3.7 \\
$\mathrm{~K}^{+}$ & -4 & 2.4 & 21.5 \\
$\mathrm{Rb}^{+}$ & -2 & 0.7 & 9.1 \\
\hline $\mathrm{LiL}^{+}$ & 7.2 & -4.0 & -38.5 \\
$\mathrm{NaL}^{+}$ & -4.7 & -8.1 & -11.7 \\
$\mathrm{KL}^{+}$ & -4.3 & 3.1 & 23.0 \\
\hline $\mathrm{L}$ & -2.9 & -7.8 & -17.0 \\
\hline
\end{tabular}

(a) Data for free cations was calculated from literature data.[28,29]

Table 4. Standard thermodynamic parameters of reactants and complexes transfers from NMF to DMSO.(a)

\begin{tabular}{cccc}
\hline \multirow{2}{*}{ Species } & $\frac{\Delta_{\mathrm{t}} \mathrm{G}^{\circ}}{\mathrm{kJ} \mathrm{mol}^{-1}}$ & $\frac{\Delta_{\mathrm{t}} \mathrm{H}^{\circ}}{\mathrm{kJ} \mathrm{mol}^{-1}}$ & $\frac{\Delta_{\mathrm{t}} \mathrm{S}^{\circ}}{\mathrm{J} \mathrm{K}^{-1} \mathrm{~mol}^{-1}}$ \\
\hline $\mathrm{Li}^{+}$ & 5 & 3.9 & -3.7 \\
$\mathrm{Na}^{+}$ & -6 & 1.3 & 24.5 \\
$\mathrm{~K}^{+}$ & -7 & 2.7 & 32.5 \\
$\mathrm{Rb}^{+}$ & -2 & 1.8 & 12.7 \\
\hline $\mathrm{NaL}^{+}$ & 4.2 & 6.3 & 4.9 \\
$\mathrm{KL}^{+}$ & 3.5 & 9.2 & 16.6 \\
\hline $\mathrm{L}$ & 3.8 & -1.7 & -19.2 \\
\hline (a) Data for free cations was calculated from literature data.[28,29]
\end{tabular}

(a) Data for free cations was calculated from literature data.[28,29]

contribution to the transfer Gibbs energies is favorable in most cases, with the exceptions of $\mathrm{Li}^{+}$and free $\mathbf{L}$. By considering and comparing the values mentioned above, the explanation of the lowest affinity of $\mathbf{L}$ towards alkali metal cations in DMSO is straightforward from the thermodynamic point of view.

\section{CONCLUSION}

The alkali metal cations complexation by calix[4]arene derivative $\mathbf{L}$ comprising tertiary amide subunits was studied in $\mathrm{N}$-methylformamide, $\mathrm{N}, \mathrm{N}$-dimethylformamide, and dimethyl sulfoxide by microcalorimetric and spectrophotometric titrations. As expected, the obtained stability constants were substantially lower in these solvents compared to less strongly cation solvating ones, like acetonitrile or methanol. However, $\mathbf{L}$ was proven to be an efficient receptor of $\mathrm{Na}^{+}$cation in all solvents used $(\log K$ $\approx 6$ ), which was, from the thermodynamic point of view, a result of rather favorable complexation enthalpy. Binding of potassium ion was observed in all three solvents, whereas complexation of $\mathrm{Li}^{+}$by $\mathbf{L}$ was not detected in DMSO, and the formation of $\mathrm{Rb}^{+}$complex occurred only in NMF. These findings could be mainly accounted for by considering the size compatibility of the macrocyclic host and cationic guests.

Thermodynamic parameters of ligand dissolution in the three solvents were determined based on van't Hoff equation, and used to quantitatively describe the solvent effect on the studied reactions. This was done by calculating and interpreting the thermodynamics of transfer from NMF to a particular solvent. It was found that the differences (as well as similarities) in the complexation ability of $\mathbf{L}$ were the result of an interesting interplay among solvation of all three species involved in the corresponding reactions, i.e. the free cation, receptor, and the complex.

The comprehensive comparative analysis of the herein reported thermodynamic data allowed us to gain an insight into the factors governing the solvation effect on the binding affinity of the explored calix[4]arene derivative towards alkali metal cations in solvents capable of strongly solvating the cations. We believe that the results presented in this work will aid to better understanding and even anticipating the solvent influence on the cation complexation equilibria in general, especially those involving macrocyclic compounds, thus facilitating the improvement and fine-tuning of their binding properties.

Acknowledgment. This work has been fully supported by Croatian Science Foundation under the project IP-2014-097309 (SupraCAR).

Supplementary Information. Supporting information to the paper is attached to the electronic version of the article at: http://doi.org/10.5562/cca3200.

\section{REFERENCES}

[1] C. D. Gutsche, Calixarenes: An Introduction, $2^{\text {nd }}$ edn., The Royal Society of Chemistry, Cambridge, 2008.

[2] B. S. Creaven, D. F. Donlon, J. McGinley, Coord. Chem. Rev. 2009, 253, 893.

[3] W. Sliwa, T. Girek, J. Incl. Phenom. Macrocycl. Chem. 2010, 66, 15.

[4] A. F. Danil de Namor, R. M. Cleverley, M. L. ZapataOrmachea, Chem. Rev. 1998, 98, 2495.

[5] I. Sviben, N. Galić, V. Tomišić, L. Frkanec, New J. Chem. 2015, 39, 6099.

[6] G. Delahousse, R. Lavendomme, I. Jabin, V. Agasse, P. Cardinael, Curr. Org. Chem. 2015, 23, 2237.

[7] B. Mokhtari, K. Pourabdollah, N. Dalali, J. Incl. Phenom. Macrocycl. Chem. 2011, 69, 1. 
[8] M. Tranfić Bakić, D. Jadreško, T. Hrenar, G. Horvat, J. Požar, N. Galić, V. Sokol, R. Tomaš, S. Alihodžić, M. Žinić, L. Frkanec, V. Tomišić, RSCAdv. 2015, 5, 23900.

[9] F. Nasuhi Pur, Mol. Divers. 2016, 20, 781.

[10] C. Mareque Rivas, H. Schwalbe, S. J. Lippard, Proc. Natl. Acad. Sci. USA, 2001, 98, 9478.

[11] S. E. Matthewsa, P. D. Beerb in Calixarenes in the Nanoworld (Eds.: J. Vicens and J. Harrowfield), Springer, 2007. pp. 109-133.

[12] Z. Xu, S. Peng, Y.-Y. Wang, J.-K.Zhang, A. I. Lazar D.S. Guo, Adv.Mater. 2016, 28, 7666.

[13] A. R. Kongor, V. A. Mehta, K. M. Modi, M. K. Panchal, S. A. Dey, U. S. Panchal,V. K. Jain, Top. Curr. Chem. 2016, 374, 28.

[14] A. Casnati, D. Sciotto, G. Arena in Calixarenes 2001 (Eds.: Z. Asfari, V. Böhmer, J. Harrowfield, J. Vicens), Kluwer Academic Publishers, Dordrecht, 2001, pp. 440-457.

[15] J. Požar, T. Preočanin, L.; Frkanec, V. Tomišić, J. Sol. Chem. 2010, 39, 835.

[16] G. Horvat, V. Stilinović, T. Hrenar, B. Kaitner, L. Frkanec, V. Tomišić, Inorg. Chem. 2012, 51, 6264.

[17] A. F. Danil de Namor, T. T. Matsufuji-Yasuda, K. Zegarra-Fernandez, O. A. Webb, A. E. Gamouz, Croat. Chem. Acta. 2013, 86, 1.
[18] F. Arnaud-Neu, S. Barboso, F. Berny, A. Casnati, N. Muzet, A. Pinalli, R. Ungaro, M. J. Schwing-Weill, G. Wipff, J. Chem. Soc. Perkin Trans. 1999, 2, 1727.

[19] G. Horvat, V. Stilinović, T. Hrenar, B. Kaitner, L. Frkanec, V. Tomišić, Inorg. Chem. 2013, 52, 12702.

[20] V. Tomišić, N. Galić, B. Bertoša, L. Frkanec, V. Simeon, M. Žinić, J. Incl. Phenom. Macrocycl. Chem. 2005, 53, 263.

[21] A. F. Danil de Namor, D. Kowalska, E. E Castellano, O. E. Piro, F. J. Sueros Velardea, Villanueva Salasa, Phys. Chem. Chem. Phys. 2001, 3, 4010.

[22] A. F. Danil de Namor, M. L. Zapata-Ormachea, R. G. Hutcherson, J. Phys. Chem. B 1999, 103, 366.

[23] A. F. Danil de Namor, M. L. Zapata-Ormachea, R. G. Hutcherson, J. Phys. Chem. B 1998, 102, 7839.

[24] A. Arudini, A. Pochini, S. Reverberi, S. Ungaro, G. D. Andreeti, F. Ugozzoli, J. Incl. Phenom. 1988, 6, 119.

[25] Origin. 2003. Origin 7.5. OriginLab Corp., Northampton, MA, http://www.originlab.com.

[26] J. Tellinghuisen, J. Phys. Chem. B 2007, 111, 11531.

[27] P. Gans, A. Sabatini, A. Vacca, Talanta 1996, 43, 1739.

[28] Marcus, Y. Ion Properties, M. Dekker, New York, 1997.

[29] C. M. Criss, M. Salomon, Physical Chemistry of Organic Solvent Systems, (Eds.: A. K. Covington, T. Dickinson), Plenum Press, London, 1973, p. 329. 